\title{
Vesicle-Trafficking Protein SEC22b
}

National Cancer Institute

\section{Source}

National Cancer Institute. Vesicle-Trafficking Protein SEC22b. NCI Thesaurus. Code C101480.

Vesicle-trafficking protein SEC22b (215 aa, $\sim 25 \mathrm{kDa}$ ) is encoded by the human SEC22B gene. This protein is involved in anterograde transport. 